\title{
4: $186122364-186051899$
}

National Cancer Institute

\section{Source}

National Cancer Institute. 4:186122364-186051899. NCI Thesaurus. Code C41641.

Physical location of ACSL1_Gene 